\title{
Stingless bee honey and its potential value: a systematic review
}

\author{
${ }^{1,4}$ Yaacob, M., ${ }^{2}$ Rajab N.F., ${ }^{3}$ Shahar, S. and ${ }^{1 *}$ Sharif, R. \\ ${ }^{1}$ Nutritional Sciences Programme, School of Healthcare Sciences, Faculty of Health Sciences, Universiti \\ Kebangsaan Malaysia \\ ${ }^{2}$ Biomedical Science Programme, Faculty of Health Sciences, Universiti Kebangsaan Malaysia \\ ${ }^{3}$ Dietetics Programme, Faculty of Health Sciences, Universiti Kebangsaan Malaysia \\ ${ }^{4}$ Faculty of Medicine and Health Sciences, Universiti Sains Islam Malaysia
}

\begin{abstract}
Article history:
Received: 6 September 2017

Received in revised form: 19

September 2017

Accepted: 22 September 2017

Available Online: 15 October 2017
\end{abstract}

\section{Keywords:}

Kelulut,

Trigona sp.,

Anti-inflammatory,

Antimicrobial,

Antioxidant

\section{DOI:}

https://doi.org/10.26656/fr.2017.2(2).212

\begin{abstract}
Modern science has found that most traditional practice of using stingless bee honey has great potential as an added value in modern medicine and considered to have a higher medicinal value than other bee species. However, due to the relatively low output of honey compared to other honey so, focus on this honey is limited. Hence, this systematic review provides the updated result on the potential value of stingless bee honey as an antioxidant, anti-inflammatory, cytotoxicity and antimicrobial. The search strategy was developed in four databases (Scopus, Medline and Ovid, EMBASE and PubMed) with the search terms "("honey" and "Kelulut", "honey" and "stingless bee", "honey" and "Trigona", "honey" and "pot honey", and "honey" and "Melipon")". The merged data was assessed using PRISMA guidelines and after the duplicates were removed, 1271 articles were segregated. Afterwards, 1232 articles were eliminated because they do not meet the inclusion criteria and 39 articles were reevaluated again for eligibility. Finally, after the evaluation process, only 26 of the articles were chosen for this review. The data of 26 articles of stingless bee honey were deliberated based on antioxidant properties, anti-inflammatory, cytotoxicity and analysis of antimicrobial activity. Three articles reported on antioxidant properties, one article on anti-inflammatory analysis, two articles on cytotoxicity analysis, and twenty articles on analysis of antimicrobial activity. Based on the feasible affirmation from the literature, stingless bee honey has an antioxidant capacity that able to decrease the ROS. ROS able to lead a variety of health problems thus stingless bee honey can be a dietary supplement to overcome this problem.
\end{abstract}

\section{Introduction}

Honey is a natural food derived from honey bee and most commonly used as a sweetener. Besides, honey also is known for its remedial value (Rodríguez et al., 2012). Even though there has a study on the potential of honey in treating several health problems but studies mostly are focusing on Tualang and Manuka honey compared to the stingless bee honey due to the low production of honey (Roowi et al., 2012). Therefore, there has no guarantee of their nutrients to the user since it not yet included in the Codex Alimentarius for honey (Codex, 2001).

Previous study showed that stingless bee honey can act as anti-inflammatory (Borsato et al., 2014), anticancer (Kustiawan et al., 2014; Yazan et al., 2016), antimicrobial (Miorin et al., 2003; Demera et al., 2004; Garedew et al., 2004; Temaru et al., 2007; Kimoto-Nira and Amano, 2008; Chanchao et al., 2009; Boorn et al.,
2010; Rodríguez et al., 2012; Ilechie et al., 2012; Andualem, 2013; Ewnetu et al., 2013; Mercês et al., 2013; Queiroz et al., 2013; Zainol et al., 2013; Nobre da Cruz et al., 2014; Massaro et al., 2014; Zamora et al., 2014; Nishio et al., 2016; Medeiros et al., 2016; De Sousa et al., 2016; Nishio et al., 2016) and possessed antioxidant properties (Duarte et al., 2012; Almeida da Silva et al., 2013; De Sousa et al., 2016). However, the beneficial of stingless bee honey has been abandoned in modern medicine due to the paucity of systematic scientific studies for supporting its medical properties (Pe'rez et al., 2006).

The composition of stingless bee honey differ from other species according to some physicochemical parameters (Özbalci et al., 2013) and other studies prove that honey from stingless bees are more valuable and it has been used for a long time to treat various diseases 
(Souza et al., 2006).

Stingless bees is a small bee from the species of Trigona or Meliponine and also known as Kelulut bee in Malaysia is the type of honey that has a high medicinal beneficial than other bee species which had alleged by the traditional medical practitioner (Biswa et al., 2017) They are the main pollinators among the other bees and can be found mostly in tropical and subtropical regions (Fowler, 1979) . The color of the honey is usually clearer, liquid and has a sweet and sour taste (Roowi et al., 2012). The recent studies showed that the stingless bee honey has the potential to treat colorectal cancer (Yazan et al., 2016), anti-inflammatory (Borsato et al., 2014), antimicrobial (Zainol et al., 2013; Nobre da Cruz et al., 2014; Massaro et al., 2014; Nishio et al., 2016; Medeiros et al., 2016; De Sousa et al., 2016; Nishio et al., 2016) and has an antioxidant property (Almeida Da Silva et al., 2013; Duarte et al., 2012).

This review aims to prove current scientific evidence regarding the stingless bee honey and its potential value on health as anti-inflammatory, cytotoxicity, antimicrobial and also the antioxidant properties.

\section{Materials and methods}

\subsection{Search strategy}

The search for articles from databases namely Scopus, Medline and Ovid, EMBASE, and PubMed were performed until October 2016. Search strategies were adjusted to well-suited with the subject headings and keywords of each database were carried out. The search terms encompass "honey" and Kelulut", "honey" and "stingless bee", "honey" and "Trigona", "honey" and "pot honey", and "honey" and "Melipon". The compatible references were re-evaluated for affirmation of the search string. In addition, pertinent reviews were also included as an additional source of literature reports. All the search databases were exported into an Endnote library to remove duplicates.

\subsection{Inclusion criteria}

Stingless bee is also known as Kelulut, Trigona spp, Melipona spp., Meliponine spp and pot honey bee in other literature. In this review, in vitro and in vivo studies that investigated the benefit of honey from stingless bee were included. From the databases, only stingless bee honey as anti-inflammatory, cytotoxicity, antimicrobial and antioxidant properties were included in this study. Studies published in English and Malay were taken into deliberation.

\subsection{Exclusion criteria}

Literature reports on propolis and behavior study of the honeybee or other species of bee were excluded from the study. The studies on physicochemical of stingless bee honey or bioactive chemical component in honey also were excluded this review.

\subsection{Study selection}

The prime literature search was executed by authors. All duplicate articles were first filtered out by a software and followed by hand search to verify there is no duplicate articles were included. Potential relevant papers were chosen by screening the title, abstract, and retrieval of the full article from the database search. Afterwards, the resulting irrelevant reports were rejected according to inclusion and exclusion criteria. After that, full-text articles were downloaded and then assessed for eligibility. If the papers were not published in English and Malay, these studies were excluded at this time point.

\subsection{Data organization and reporting}

The information acquired from each study were arranged particularly according to the data about the author's name, year of publication, type of cell or bacteria used, type of stingless bee species, experimental method, and outcomes. The inclusion studies were reported according to PRISMA guidelines (http:// www.prisma-statement.org/statement.htm). PRISMA also provides a flowchart to illustrate the searching strategy until the assessment process.

\section{Results}

\subsection{Descriptive of selected studies}

Figure 1 is an illustration of the procedure for the study selection. A total of 1796 articles were found after searching in four differences databases. 1271 articles were segregated after removal of duplicates. Afterwards, 1232 articles were rejected because they did not fulfill the inclusion criteria and 39 articles were reevaluated again for the qualification. Finally, 13 articles which were not written in English or Malay language were removed and only 26 of the reports were deliberated for this review. All the 26 reports were found and further analysis regarding the type of honey from difference stingless bee species and outcomes were summarized in Tables 1-4.

\subsection{Antioxidant properties of stingless bee honey}

The clinical finding reported that oxidative stress can 


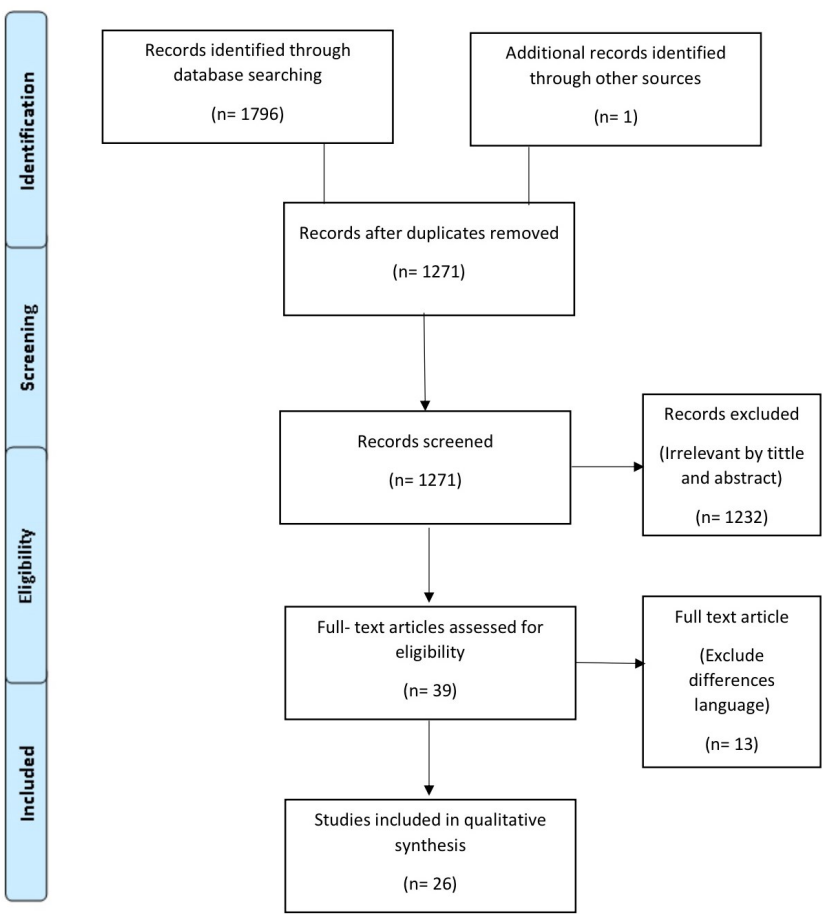

Figure 1. Flowchart of search strategy and selection process

cause oxidative damage to deoxyribonucleic acid (DNA), proteins, and fats and antioxidants can stop or slow down the process of oxidative stress in the cell (Block et al., 2002). Oxidative stress can lead the development of neurological diseases (Alzheimer's disease and Parkinson's disease), atherosclerosis, joint disorders, cardiovascular diseases, lung and kidney disorders, eye disorders, cancer, aging and other degenerative diseases (Rahman et al., 2012). Therefore, antioxidant properties such as phenolic acid can decrease the oxidative stress.

Total phenolic content differs among the honey regarding their type of bee species, region, season and type of floral sources (Almeida da Silva et al., 2013). Although Apis spp. is more recognize compared to the species from a stingless bee, but the total phenolic acid of stingless bee from species Plebeia spp. was higher than Apis spp. which is $106.01 \pm 9.85 \mathrm{mg}$ GA equivalent/ $100 \mathrm{~g}$ compared to Apis sp. $92.34 \pm 13.55 \mathrm{mg}$ GA acid equivalent/ $100 \mathrm{~g}$ (Duarte et al., 2012). Meanwhile for antioxidant activity of Plebeia spp. is $49.91 \pm 21.36 \mathrm{mg}$ GA equivalent/ $100 \mathrm{~g}$. Moreover, Almeida da Silva et al. (2013) reported that honey sample which displayed the highest total phenolic content have slightly highest $\mathrm{ABTS}^{+}$cation radical scavenging capacity. This result indicates that there is a correlation between phenolic content and antioxidant activity in the stingless bee's honey (Duarte et al., 2012; De Sousa et al., 2016).

\subsection{Biology action of antioxidant activity}

\subsubsection{Anti-inflammatory}

Previous literature reported that phenolic compound had related to anti-inflammatory effects on the animal (Larrosa et al., 2009). Caffeic and ferulic acids, the derivatives from phenolic acid can reduce inflammation in neurovascular and able to inhibit macrophage inflammatory protein-2 (MIP-2) (Larrosa et al., 2009). Meanwhile, kaempferol showed an inhibitory effect on NO synthase (iNOS) and cyclooxygenase- 2 (COX-2) (Crespo et al., 2008). The studies conducted by Borsato et al. (2014) proved that phenolic acid from an extract of honey from stingless bee had decreased the production of reactive oxygen species (ROS) in $55 \pm 14 \%$. A study done by Larrosa et al. (2009) is the early report described the anti-inflammatory activity of honey extract from stingless bee species (M. marginata) by in vivo approaches thus, conclude that the stingless bee honey able to decrease ear edema (Borsato et al., 2014).

\subsubsection{Anti-proliferative}

There had very few studies anti- proliferative of stingless bee honey on cancer cell lines. The previous studies showed the stingless bee honey showed cytotoxically sensitive to the liver hepatocellular carcinoma cell lines (HepG2) and lung bronchus carcinoma cell line (ChaGo- I). In contrast, colon carcinoma cell lines (SW620), human gastric carcinoma cell lines (KATO-III) and ductal carcinoma cell lines (BT474) were insensitive to honey (Kustiawan et al., 2014). This showed that the honey can gave a different effect on various cell lines (Porcza et al., 2016). Further studies on cytotoxicity activity of the known pure compound of kaempferol, apigenin, caffeic acid phenethyl ester (CAPE), and narigenin which are derived from phenolic acid in honey were investigated (Yazan et al., 2016). The results revealed that these compounds have cytotoxic effects on the ChaGo-I and KATO-III cell lines, KATO-III and BT474 respectively (Kustiawan et al., 2014; Yazan et al., 2016). This suggests that each compound from phenolic acid can be cytotoxic to the tested cancer cell. Meanwhile, another studied done on Sprague Dawley rats which are induced with colorectal cancer shown that the stingless bee honey able to reduce the total number of aberrant crypts (AC), crypt multiplicity and aberrant crypt foci (AFC) thus, indicated the potential of the honey as chemo-preventive agent (Yazan et al., 2016).

\subsubsection{Antimicrobial}

The antimicrobial activities of honey were reported due to phytochemicals, acidity, high osmolarity, and the presence of hydrogen peroxide in the honey (Molan, 1992). From the Table 4, honey from stingless bee has a 


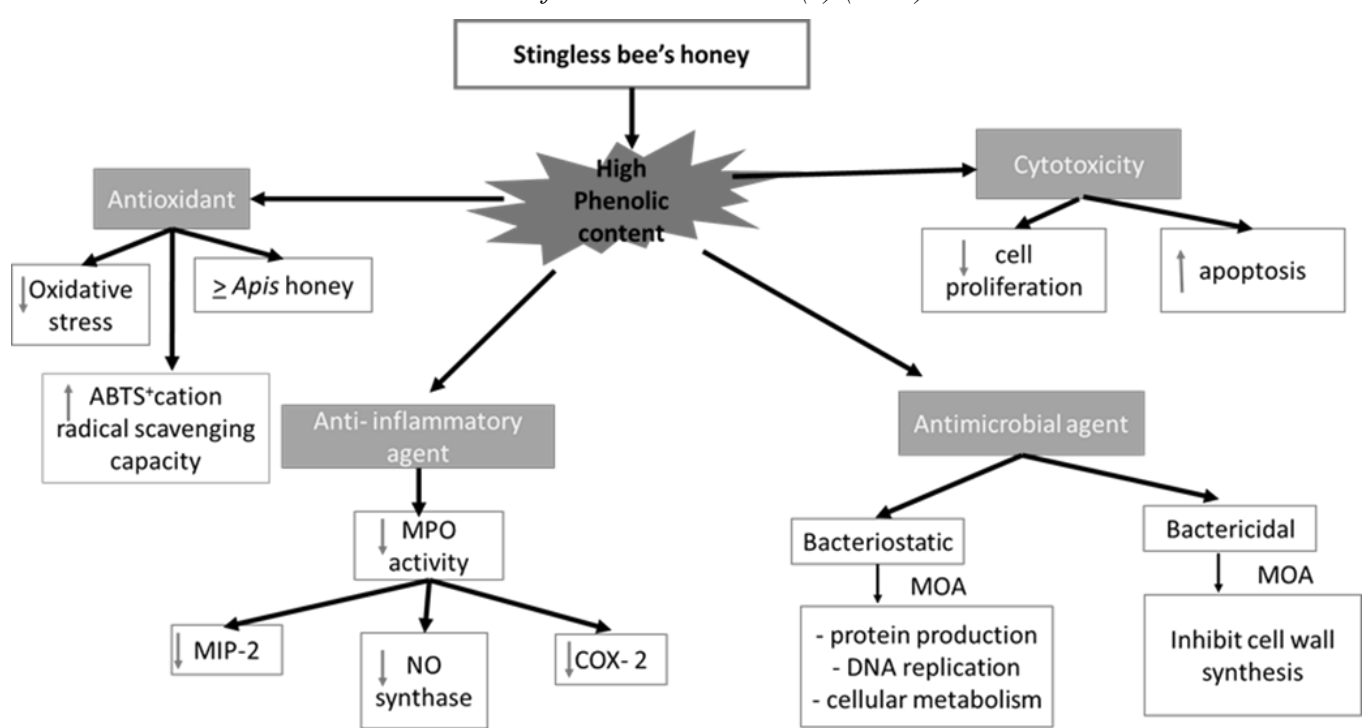

Figure 2. Schematic diagram on the potential effects of stingless bee's honey to enhance better life. Abbreviations: ABTS ${ }^{+}, 2$, 2'-azino-bis (3-ethylbenzothiazoline-6-sulphonic acid); MPO, Myeloperoxidase; MIP-2, macrophage inflammatory protein-2; COX-2, cyclooxygenase-2; MOA, mode of action

Table 1. Antioxidant analysis of stingless bee honey.

\begin{tabular}{|c|c|c|c|}
\hline $\begin{array}{l}\text { Authors and } \\
\text { Year }\end{array}$ & Types & Method & Outcomes \\
\hline $\begin{array}{l}\text { De Sousa et al. } \\
\qquad(2016)\end{array}$ & $\begin{array}{l}\text { M. subnitida Ducke and } \\
\text { M. scutellaris Latrelle }\end{array}$ & $\begin{array}{l}\text { ABTS cation radical scav- } \\
\text { enging and DPPH scaveng- } \\
\text { ing method }\end{array}$ & $\begin{array}{l}\text { Honey of } M . \text { subnitida Ducke showed the } \\
\text { higher antioxidant activity compared to } M \text {. } \\
\text { scutellaris Latrelle in both assays. }\end{array}$ \\
\hline $\begin{array}{l}\text { Almeida da } \\
\text { Silva et al. } \\
\text { (2013) }\end{array}$ & $\begin{array}{l}\text { Melipona (Michmelia) } \\
\text { seminigra merrillae) }\end{array}$ & $\begin{array}{l}\text { ABTS cation radical scav- } \\
\text { enging }\end{array}$ & $\begin{array}{l}\text { The samples showed the highest antioxidant } \\
\text { capacity has a higher total phenolic content. }\end{array}$ \\
\hline $\begin{array}{l}\text { Duarte } \text { et al. } \\
\text { (2012) }\end{array}$ & Plebeia spp. & $\begin{array}{l}\text { Ferric reducing antioxidant } \\
\text { power (FRAP) assay and } \\
\text { (DPPH) scavenging assay }\end{array}$ & $\begin{array}{l}\text { Honey from Plebeia spp. has higher content } \\
\text { of total phenolics, flavonoids and antioxi- } \\
\text { dants capacity compared to Apis sp. }\end{array}$ \\
\hline
\end{tabular}

Table 2. Anti-inflammatory analysis of stingless bee honey.

\begin{tabular}{|c|c|c|c|c|}
\hline $\begin{array}{l}\text { Authors } \\
\text { and Year }\end{array}$ & $\begin{array}{c}\text { Study } \\
\text { population }\end{array}$ & Types & Method & Outcomes \\
\hline $\begin{array}{l}\text { Borsato } \\
\text { et al. } \\
\text { (2014) }\end{array}$ & $\begin{array}{l}\text { Animals. } \\
\text { Male Swiss } \\
\text { mice }\end{array}$ & $\begin{array}{l}\text { Stingless bee from } \\
\text { species Melipona } \\
\text { marginata }\end{array}$ & $\begin{array}{l}\text { Mice induced with } 12-\mathrm{O}- \\
\text { tetradecanoylphorbol- } 13 \text { - } \\
\text { acetate- induced for ear edema model. }\end{array}$ & $\begin{array}{l}\text { The honey extract }(1.0 \mathrm{mg} / \mathrm{ear}) \\
\text { had the ability to reduce ear edema } \\
\text { with an inhibitory effect of } 54 \pm \\
5 \% \text {. }\end{array}$ \\
\hline
\end{tabular}

Table 3. Cytotoxicity studies of stingless bee honey

\begin{tabular}{|c|c|c|c|c|}
\hline $\begin{array}{c}\text { Authors and } \\
\text { Year }\end{array}$ & $\begin{array}{c}\text { Study } \\
\text { population }\end{array}$ & Types & Method & Outcomes \\
\hline $\begin{array}{l}\text { Yazan et al. } \\
(2016)\end{array}$ & $\begin{array}{l}\text { Sprague } \\
\text { Dawley rats } \\
\text { aged } 5 \\
\text { weeks ( } \mathrm{n}= \\
24)\end{array}$ & $\begin{array}{l}\text { Honey from } \\
\text { Trigona } \text { sp. }\end{array}$ & $\begin{array}{l}\text { Rats were injected with azoxymethane } \\
(15 \mathrm{mg} / \mathrm{kg}) \text { and the treatment groups } \\
\text { were given via oral administration of } \\
\text { Kelulut honey (1183mg } / \mathrm{kg} \text { body } \\
\text { weight }) \text { twice per day for } 8 \text { weeks. }\end{array}$ & $\begin{array}{l}\text { The total number of aberrant crypt } \\
\text { foci (ACF) and aberrant crypts } \\
\text { (AC) and crypt multiplicity were } \\
\text { significantly reduced. This } \\
\text { suggests that stingless bee honey } \\
\text { has chemopreventive properties. }\end{array}$ \\
\hline $\begin{array}{l}\text { Kustiawan et } \\
\text { al. (2014) }\end{array}$ & $\begin{array}{l}\begin{array}{l}\text { Human } \\
\text { cancer cell } \\
\text { lines }\end{array} \\
\text { HepG2 } \\
\text { SW620 } \\
\text { ChaGo- 1 } \\
\text { KATO- III } \\
\text { BT474 }\end{array}$ & $\begin{array}{l}\text { Trigona incisa, } \\
\text { Trigona apicalis, } \\
\text { T. fuscobalteata, } \\
\text { T. fuscibisca }\end{array}$ & $\begin{array}{l}\text { Crude extract was screened for in } \\
\text { vitro cytotoxicity against the cell lines } \\
\text { using the } 3-(4,5 \text { - dimethylthiazol- } 2 \text { - } \\
\text { yl) - } 2,5 \text { - diphenyltetrazolium } \\
\text { bromide assay. }\end{array}$ & $\begin{array}{l}\text { Crude extract of stingless bee has } \\
\text { cytotoxic effect to HepG } 2 \text { cell } \\
\text { line. }\end{array}$ \\
\hline
\end{tabular}


broad spectrum antibacterial activity because honey can act against a wide range of bacteria that able to cause disease (Boorn et al., 2010; Nishio et al., 2016). Most of the studies of honey were performed on Staphylococcus aureus (Miorin et al., 2003; Demera et al., 2004; Temaru et al., 2007; Chanchao et al., 2009; Boorn et al., 2010; Chan- Rodriguez et al., 2012; Ilechie et al., 2012; Andualem et al., 2013; Ewnetu et al., 2013; Merces et al., 2013; Queiroz et al., 2013; Zainol et al., 2013; Nobre da Cruz et al., 2014; Massaro et al., 2014; Zamora et al., 2014) showed that it is the most susceptible tested pathogen to stingless bee honey. As we know, Staphylococcus aureus is a common pathogen found in human skin and can cause infection in the presence of a wound. From the studies, bee honey can reduce the risk of infection to humans by this pathogen. Meanwhile, De Sousa et al. (2016) and Chan- Rodriguez et al. (2012) stated that this honey can control the foodborne disease by inhibiting the foodborne organism such as Escherichia coli and Staphylococcus aureus. Stingless bee honey also can be shortened the infections time for eye diseases caused by Staphylococcus aureus and Pseudomonas aeruginosa which were studied on as a model (Ilechie et al., 2012). Moreover, a study done by Kimoto-Nira and Amano (2008) proved that stingless bee honey able to protect against gastrointestinal infection in humans. Due to the emerging of the antibiotic resistant bacteria such as Methicillin-resistant Staphylococcus aureus (MRSA), the potential of the honey to become an antibacterial agent to against this problem were proved by studies done by Nishio et al. (2016) and Medeiros et al. (2016).

\section{Discussion}

This systematic review identified 26 reports on antioxidant properties of stingless bee honey and its potential value on health as anti-inflammatory, cytotoxicity, and antimicrobial (Figure 2). There are 2 studies on antioxidant properties that revealed the correlation between the total phenolic content and antioxidant properties (Duarte et al., 2012; Almeida da Silva et al., 2013). Generally, phenolic content plays a role to reduce the disease that associated with oxidative stress. By the presence of this active compound, it makes the stingless bee honey valuable for medical purpose. Meanwhile, another paper focusing on stingless bee honey from a variety of sample from differences locations which is best to know either the total phenolic compound and antioxidant are vary depending on geographic and type of floral used. The antioxidant properties also varied depend on soil type although mainly due to the type of floral sources.

The study conducted by Borsato et al. (2014) indicates that stingless bee honey extract has a topical anti-inflammatory activity by reducing the production of reactive oxygen species, leukocyte migration and as well as reduced edema. From the study, they are comparing the correlation between the presence of the phenolic compound in the stingless bee honey with the antiinflammatory effects. This is the good experimental paper which it determines anti-inflammatory by measurement ear thickness before and after treatment in which referring to the inflammation condition and also histological analysis. Moreover, this is the first report describing the anti-inflammatory activity of stingless bee honey extract by using in vivo approaches and this can lead more studies on the anti-inflammatory effect of the honey and can make it be a potential therapeutic opportunity against inflammatory (Borsato et al., 2014).

From the study done by Kuatiawan et al. (2014), stingless bee honey showed a cytotoxicity effect to most of the cell lines. Honey has a broad target of mechanism to become cytotoxic to the cell either act as antiproliferative or apoptotic (Porcza et al. 2016). Meanwhile for the ex-vivo experimental designed by the Yazan et al. (2016) by using the Sprague Dawley rats induced with colorectal cancer is the good platform to show the overall effect of the honey on the living subject.

Due to a shortage of new development of antibiotic to combat with the bacteria and multidrug resistance bacteria, usage of honey as an antimicrobial agent might be promising. Antimicrobial properties of honey may be related to the presence of flavonoids (Miorin et al., 2003). Flavonoids also can combat oxidative stress as well as inhibit the pathogens (Shashank and Abhay, 2013)

\section{Conclusion}

From the studies, stingless bee honey showed a potential for use in medicine as it contains phenolic that increases antioxidant content as well as it can decrease oxidative stress-related diseases.

\section{Conflict of Interest}

No potential conflict of interest was reported by the authors. 
Table 4. Antimicrobial studies of stingless bee honey

\begin{tabular}{|c|c|c|c|c|}
\hline $\begin{array}{l}\text { Authors } \\
\text { and Year }\end{array}$ & Study population & Types & Method & Outcomes \\
\hline $\begin{array}{l}\text { Nishio et } \\
\text { al. } \\
(2016)\end{array}$ & $\begin{array}{l}\text { Methicillin-resistant } S \text {. aureus } \\
\text { (MRSA) and Methicillin-sensitive } \\
\text { S. aureus (MSSA) }\end{array}$ & $\begin{array}{l}\text { Scaptotrigona } \\
\text { postica }(\mathrm{H} 6) \\
\text { and } \\
\text { Scaptotrigona } \\
\text { bipunctata } \\
\text { (H7) }\end{array}$ & 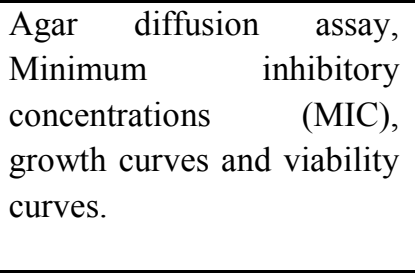 & $\begin{array}{l}\text { The inhibition zones generated } \\
\text { by the honey samples ranged } \\
\text { from } 20 \mathrm{~mm} \text { to } 27 \mathrm{~mm} \text { and } \\
\text { MIC values ranged from } 0.62 \\
\text { to } 12.5 \% \text {. }\end{array}$ \\
\hline $\begin{array}{l}\text { Medeiros } \\
\text { et al. } \\
(2016)\end{array}$ & $\begin{array}{l}\text { MRSA- infected wounds of rats } \\
(\mathrm{n}=24)\end{array}$ & $\begin{array}{l}\text { Melipona } \\
\text { scutellaris }\end{array}$ & $\begin{array}{l}\text { The uninfected skin } \\
\text { wounds of rats were treated } \\
\text { with honey and inoculated } \\
\text { with MRSA ATTC43300. } \\
\text { Bacterial culture and } \\
\text { wound biopsies was } \\
\text { performed. }\end{array}$ & \begin{tabular}{llr} 
Honey of & \multicolumn{2}{r}{ Melipona } \\
scutellaris & inhibit the \\
bacterial growth and \\
increase the cytokine \\
expression.
\end{tabular} \\
\hline $\begin{array}{l}\text { De sousa } \\
\text { et al. } \\
(2016)\end{array}$ & $\begin{array}{l}\text { Listeria monocytogenes, } S . \\
\text { aureus, E. coli, Salmonella sp., } \\
\text { and } P \text {. aeruginosa. }\end{array}$ & $\begin{array}{l}\text { M. subnitida } \\
\text { Ducke and } M . \\
\text { scutellaris } \\
\text { Latrelle }\end{array}$ & $\begin{array}{l}\text { Minimum inhibitory } \\
\text { concentration (MIC) }\end{array}$ & $\begin{array}{l}\text { Gram-positive bacteria is more } \\
\text { sensitive to the tested honey } \\
\text { compared to Gram-negative } \\
\text { bacteria. }\end{array}$ \\
\hline $\begin{array}{l}\text { Nishio et } \\
\text { al. } \\
(2016)\end{array}$ & $\begin{array}{l}\text { E. faecalis, E. faecium, E. coli, } K \text {. } \\
\text { pneumoniae, } P . \text { aeruginosa, } S . \\
\text { enterica Enteritidis, S. enterica } \\
\text { Thyphimurium, S. aureus, MRSA, } \\
\text { S. epidermidis, S. mutans, and } S . \\
\text { pyogenes. }\end{array}$ & $\begin{array}{l}\text { Scaptotrigona } \\
\text { bipunctata } \\
\text { Lepeletier } \\
\text { (SB)and } S . \\
\text { postica } \\
\text { Latreille (SP) }\end{array}$ & $\begin{array}{l}\text { Agar well diffusion, } \\
\text { minimum } \\
\text { concentrations } \\
\text { construction of growth and } \\
\text { viability curves and } \\
\text { scanning } \\
\text { microscopy (SEM) }\end{array}$ & $\begin{array}{l}\text { The MICs value of honey } \\
\text { ranged from } 0.62 \% \text { to } 10 \% \\
\text { meanwhile for the inhibition } \\
\text { zones ranged from } 8 \text { to } 22 \\
\text { mm. SEM images the } \\
\text { disruption of cell wall for both } \\
\text { honeys. }\end{array}$ \\
\hline $\begin{array}{l}\text { Nobre da } \\
\text { Cruz et } \\
\text { al. } \\
(2014)\end{array}$ & $\begin{array}{l}\text { Staphylococcus aureus, } \\
\text { Enterococcus faecalis, } \\
\text { Escherichia coli, } \\
\text { Chromobacterium violaceum, } \\
\text { and Candida albicans. }\end{array}$ & $\begin{array}{l}\text { Melipona } \\
\text { compressipes, } \\
\text { Melipona } \\
\text { seminigra }\end{array}$ & $\begin{array}{l}\text { Minimum inhibitory } \\
\text { concentrations (MIC) }\end{array}$ & $\begin{array}{l}\text { All tested honeys at } \\
\text { concentrations able to inhibit } \\
\text { S. aureus, E. faecalis, E. coli, } \\
\text { C. violaceum and C. albicans. }\end{array}$ \\
\hline $\begin{array}{l}\text { Massaro } \\
\text { et al. } \\
(2014)\end{array}$ & $\begin{array}{l}\text { Staphylococcus aureus (ATCC } \\
\text { 25923) and Klebsiella } \\
\text { pneumoniae (ATCC 13883) }\end{array}$ & $\begin{array}{l}\text { Australian } \\
\text { stingless bee } \\
\text { honey }\end{array}$ & $\begin{array}{l}\text { Agar diffusion and broth } \\
\text { dilution assays }\end{array}$ & $\begin{array}{l}\text { Raw honey were active against } \\
\text { both bacterial strains. } \\
\text { However, the phenolic extracts } \\
\text { inhibited only } S \text {. aureus } \\
\text { growth. }\end{array}$ \\
\hline $\begin{array}{l}\text { Zamora } \\
\text { et al. } \\
(2014)\end{array}$ & $\begin{array}{l}\text { Staphylococcus aureus (ATCC } \\
\text { 25923), Listeria monocytogenes } \\
\text { (ATCC 19116), Escherichia coli } \\
\text { (ATCC 25922), Salmonella } \\
\text { enteritidis (ATCC 13076), } \\
\text { Pseudomonas aeruginosa (ATCC } \\
\text { 9027), Staphylococcus } \\
\text { epidermidis (UCR 2902) and } \\
\text { Candida albicans (ATCC } \\
\text { 10231). }\end{array}$ & $\begin{array}{l}\text { Meliponini } \\
\text { bees. }\end{array}$ & $\begin{array}{l}\text { Minimum inhibitory } \\
\text { concentration (MIC) assay }\end{array}$ & $\begin{array}{l}\text { The honey inhibits } P \text {. } \\
\text { aeruginosa, } S \text {. aureus, and } C \text {. } \\
\text { albicans. }\end{array}$ \\
\hline $\begin{array}{l}\text { Ewnetu } \\
\text { et al. } \\
(2013)\end{array}$ & $\begin{array}{l}\text { Staphylococcus aureus (ATCC } \\
\text { 25923), Escherichia coli (ATCC } \\
\text { 25922) and Methicillin-resistant } \\
\text { Staphylococcus aureus(MRSA), } \\
\text { Escherichia coli(R) and } \\
\text { Klebsiella pneumoniae (R) }\end{array}$ & $\begin{array}{l}\text { Stingless bees } \\
\text { from northern } \\
\text { and north } \\
\text { western } \\
\text { Ethiopia }\end{array}$ & $\begin{array}{l}\text { Minimum inhibitory } \\
\text { concentration (MIC) and } \\
\text { minimum bactericidal } \\
\text { concentration (MBC) }\end{array}$ & $\begin{array}{l}\text { Honey of the stingless bees } \\
\text { has the highest inhibition zone } \\
(22.27 \pm 3.79 \mathrm{~mm}) \text { compared } \\
\text { to Apis honey. MICs value for } \\
\text { stingless bees honey is } 6.25 \% \\
(6.25 \mathrm{mg} / \mathrm{ml}) \text { of the test } \\
\text { organisms. }\end{array}$ \\
\hline
\end{tabular}


Table 4. Antimicrobial studies of stingless bee honey (cont.)

\begin{tabular}{|c|c|c|c|c|}
\hline $\begin{array}{l}\text { Authors } \\
\text { and Year }\end{array}$ & Study population & Types & Method & Outcomes \\
\hline $\begin{array}{l}\text { Mercês } \\
\text { et al. } \\
(2013)\end{array}$ & $\begin{array}{l}\text { Escherichia coli, } \\
\text { Staphylococcus aureus, } \\
\text { Pseudomonas aeruginosa, } \\
\text { Candida albicans }\end{array}$ & $\begin{array}{l}\text { Melipona asilvai, } \\
\text { Melipona } \\
\text { quadrifasciata } \\
\text { anthidioides, } \\
\text { Friseomelita } \\
\text { doederleinei, } \\
\text { Tetragonisca } \\
\text { angustula } \text { and } \\
\text { Plebeia sp. }\end{array}$ & $\begin{array}{l}\text { The agar well } \\
\text { diffusion assay }\end{array}$ & $\begin{array}{l}\text { All honey inhibit } S \text {. aureus, } \\
\text { meanwhile honey from } M \text {. } \\
\text { quadrifasciata anthidioides and } \\
F \text {. doederleinei inhibited } E \text {. coli. }\end{array}$ \\
\hline $\begin{array}{l}\text { Queiroz } \\
\text { Pimentel } \\
\text { et al. } \\
(2013)\end{array}$ & $\begin{array}{l}\text { Staphylococcus aureus, } \\
\text { Escherichia coli (0157: H7), } \\
\text { Proteus vulgaris, Shigella } \\
\text { sonnei and Klebsiella sp. } \\
\end{array}$ & $\begin{array}{l}\text { M. compressipes } \\
\text { manaosensis. }\end{array}$ & $\begin{array}{l}\text { Agar-well diffusion } \\
\text { and broth } \\
\text { macrodilution }\end{array}$ & $\begin{array}{l}\text { Honey inhibited the growth of } S \text {. } \\
\text { aureus, E. coli (0157: H7), } P \text {. } \\
\text { vulgaris, } S . \quad \text { sonnei and } \\
\text { Klebsiella sp. }\end{array}$ \\
\hline $\begin{array}{l}\text { Zainol et } \\
\text { al. } \\
(2013)\end{array}$ & $\begin{array}{l}\text { Staphylococcus aureus, } \\
\text { Bacillus cereus, Escherichia } \\
\text { coli, and Pseudomonas } \\
\text { aeruginosa. }\end{array}$ & Kelulut honey & $\begin{array}{l}\text { Minimum Inhibitory } \\
\text { Concentration (MIC) } \\
\text { and Minimum } \\
\text { Bactericidal } \\
\text { Concentration } \\
\text { (MBC) }\end{array}$ & $\begin{array}{l}\text { S. aureus were inhibited by } \\
\text { Kelulut honey with } 26.49 \\
\text { equivalent phenol concentrations } \\
\text { (EPC) compared to other } \\
\text { bacteria. }\end{array}$ \\
\hline $\begin{array}{l}\text { Rodrígu } \\
\text { ez et al. } \\
(2012)\end{array}$ & $\begin{array}{l}\text { Staphylococcus aureus (ATCC } \\
\text { 25923) and (H08M06), } \\
\text { Escherichia coli (ATCC 35922) } \\
\text { and (H12K06) and } \\
\text { Enterococcus faecalis (ATCC } \\
\text { 27853) and (H05C06) }\end{array}$ & Melipona honey & $\begin{array}{l}\text { Minimum inhibitory } \\
\text { concentrations }\end{array}$ & $\begin{array}{l}\text { Melipona honey inhibited both } \\
\text { Staphylococcus } \\
\text { ATCC25923 aureus } \\
\text { strains and both Escherichia coli } \\
\begin{array}{l}\text { ATCC35922 and H12K06 } \\
\text { strains. }\end{array}\end{array}$ \\
\hline $\begin{array}{l}\text { Ilechie } \\
\text { et al. } \\
(2012)\end{array}$ & $\begin{array}{l}\text { Bacterial conjunctivitis caused } \\
\text { by Staphylococcus aureus or } \\
\text { Pseudomonas aeruginosa was } \\
\text { induced in Hartley guinea pigs }\end{array}$ & Meliponula spp. & $\begin{array}{l}1 \text { drop }(70 \mu \mathrm{L}) \text { of } \\
\text { crude stingless bee } \\
\text { honey were applied } \\
\text { twice daily. }\end{array}$ & $\begin{array}{l}\text { The time of infections of eye } \\
\text { diseases from those bacteria } \\
\text { were shortened. }\end{array}$ \\
\hline $\begin{array}{l}\text { Boorn et } \\
\text { al. } \\
(2010)\end{array}$ & $\begin{array}{l}\text { Gram-positive bacteria, Gram- } \\
\text { negative bacteria and Candida } \\
\text { spp. }\end{array}$ & Trigona carbonaria & $\begin{array}{l}\text { Agar diffusion, agar } \\
\text { dilution, broth } \\
\text { microdilution and } \\
\text { time-kill viability } \\
\text { assays. }\end{array}$ & $\begin{array}{l}\text { Stingless bee honey has } \\
\text { antibacterial activity against all } \\
\text { the tested bacteria but very } \\
\text { limited to Candida spp. }\end{array}$ \\
\hline $\begin{array}{l}\text { Chancha } \\
\text { o et al. } \\
(2009)\end{array}$ & $\begin{array}{l}\text { Staphylococcus aureus (ATCC } \\
\text { 25923), Escherichia coli } \\
\text { (ATCC 35218), Candida } \\
\text { albicans (ATCC 10231), } \\
\text { Auriobasidium pullulans } \\
\text { (ATCC 11942) and Aspergillus } \\
\text { niger (ATCC 16404) }\end{array}$ & Trigona carbonaria & $\begin{array}{l}\text { Agar Diffusion, Agar } \\
\text { dilution broth } \\
\text { microdilution and } \\
\text { time-kill viability } \\
\text { assays }\end{array}$ & $\begin{array}{l}\text { Stingless bee honey can inhibit } \\
\text { all the tested microorganism but } \\
\text { very limited when tested with } \\
\text { Candida albicans. }\end{array}$ \\
\hline $\begin{array}{l}\text { Kimoto- } \\
\text { Nira and } \\
\text { Amano, } \\
(2008)\end{array}$ & $\begin{array}{l}\text { Lactococcus lactis (MAFF } \\
\text { 400103), Lactococcus cremoris } \\
\text { (MAFF 40007), } \\
\text { Lactobacillus casei (JCM } \\
\text { 1134), } \\
\text { Enterococcus faecalis (IFO } \\
\text { 12964), Enterococcus faecium } \\
\text { (IFO 13712) Klebsiella } \\
\text { pneumoniae ssp. (NGRI G-1), } \\
\text { Staphylococcus } \text { sp. (K-2). }\end{array}$ & $\begin{array}{l}\text { Melipona, } \\
\text { Scaptotrigona, and } \\
\text { Trigona }\end{array}$ & Disc assay & $\begin{array}{l}\text { Ten of the } 18 \text { samples of tested } \\
\text { honey inhibit Enterococcus, } \\
\text { Lactococcus, Lactobacillus, and } \\
\text { Staphylococcus strains. } \\
\text { Meanwhile, Lactococcus lactis } \\
\text { MAFF } 400103 \text { was sensitive to } \\
\text { the all tested honey samples. }\end{array}$ \\
\hline $\begin{array}{l}\text { Temaru } \\
\text { et al. } \\
(2007)\end{array}$ & $\begin{array}{l}\text { Staphylococcus aureus, } \\
\text { Enterococcus faecalis, } \\
\text { Escherichia coli and } \\
\text { Pseudomonas aeruginosa }\end{array}$ & Meliponinae & $\begin{array}{l}\text { Agar well diffusion } \\
\text { assay }\end{array}$ & $\begin{array}{l}\text { Inhibited the growth of test } \\
\text { strains }\end{array}$ \\
\hline
\end{tabular}


Table 4. Antimicrobial studies of stingless bee honey (cont.)

\begin{tabular}{|c|c|c|c|c|}
\hline $\begin{array}{l}\text { Authors } \\
\text { and Year }\end{array}$ & Study population & Types & Method & Outcomes \\
\hline $\begin{array}{l}\text { Demera } \\
\text { et al. } \\
(2004)\end{array}$ & $\begin{array}{l}\text { Bacillus cereus (ATCC 31430), } \\
\text { Pseudomonas aeruginosa (ATCC 27858), } \\
\text { Staphylococcus } \\
\text { aureus (ATCC } 6538 \text { P) and Saccharomyces } \\
\text { cerevisiae (ATCC 287), Candida albicans } \\
\text { (ATCC 90028) }\end{array}$ & $\begin{array}{l}\text { Tetragonisca } \\
\text { angustula }\end{array}$ & $\begin{array}{l}\text { The agar well } \\
\text { diffusion method }\end{array}$ & $\begin{array}{l}\text { Honey had antimicrobial } \\
\text { activity and susceptibility } \\
\text { to yeasts. }\end{array}$ \\
\hline $\begin{array}{l}\text { Garedew } \\
\text { et al. } \\
(2004)\end{array}$ & $\begin{array}{l}\text { Bacillus subtilis (DSM 347), Micrococcus } \\
\text { luteus (DSM 348), Bacillus megaterium } \\
\text { (DSM 90), Bacillus brevis (DSM 5609), } \\
\text { Escherichia coli (DSM 31) and } \\
\text { Pseudomonas syringae (DSM 5176). }\end{array}$ & $\begin{array}{l}\text { Stingless bee } \\
\text { honeys }\end{array}$ & Flow calorimetric & $\begin{array}{l}\text { Both Gram-positive and } \\
\text { Gram-negative bacteria } \\
\text { inhibited by stingless bee } \\
\text { honey. }\end{array}$ \\
\hline $\begin{array}{l}\text { Miorin et } \\
\text { al. } \\
(2003)\end{array}$ & Staphylococcus aureus & $\begin{array}{l}\text { Tetragonisca } \\
\text { angustula }\end{array}$ & $\begin{array}{l}\text { The minimum } \\
\text { inhibitory } \\
\text { concentration }\end{array}$ & $\begin{array}{l}\text { The minimum inhibitory } \\
\text { concentration is from } \\
142.87 \text { to } 214.33 \mathrm{mg} \mathrm{ml}^{-1} \text {. }\end{array}$ \\
\hline
\end{tabular}

\section{Acknowledgments}

This study was funded by the Ministry of Higher Education Malaysia under Fundamental Research Grant Scheme (FRGS), (FRGS/1/2016/SKK05/UKM/02/1) UKM.

\section{References}

Almeida da Silva, I.A., Sarmento da Silva, T.M., Camara, C.A., Queiroz, N., Magnani, M., Santos de Novais, J., Soledade, L.E.B., Edeltrudes de Oliveira, L., Lucia de Souza, A. and Gouveia de Souza, A. (2013). Phenolic profile, antioxidant activity and palynological analysis of stingless bee honey from Amazonas, Northern Brazil. Food Chemistry, 141, 3552-3558.https://doi.org/10.1016/

j.foodchem.2013.06.072

Andualem, B. (2013). Combined antibacterial activity of stingless bee (Apis mellipodae) honey and garlic (Allium sativum) extracts against standard and clinical pathogenic bacteria. Asian Pacific Journal of Tropical Biomedicine, 3(9), 725-731. https:// doi.org/10.1016/S2221-1691(13)60146-X

Biswa, R., Sarkar, A. and Subba, S.K. 2017. Ethnomedicinal uses of honey of stingless bee by Nepali community of Darjeeling foothills of West Bengal, India, p. 648-653. India: NISCAIR-CSIR.

Block G., Dietrich. M., Norkus E.P., Morrow J.D., Hudes M., Caan, B. and Packer, L. (2002). Factors Associated with Oxidative Stress in Human Populations. American Journal of Epidemiology, 156 (3), 274-285. https://doi.org/10.1093/aje/kwf029

Boorn, K.L., Khor, Y.Y., Sweetman, E., Tan, F., Heard, T.A. and Hammer, K.A. (2010). Antimicrobial activity of honey from the stingless bee Trigona carbonaria determined by agar diffusion, agar dilution, broth microdilution and time-kill methodology. Journal of Applied Microbiology, 108, 1534-1543.https://doi.org/10.1111/j.13652672.2009.04552.x

Borsato, D.M, Prudente, A.S, Boscardin, P.M., Borsato, A.V., Luz, C.F.P., Beatriz, H.L., Maia, N.S., Cabrini, D.A., Otuki, M.F., Miguel, M.D., Farago, P.V. and Miguel, O.G. (2014). Topical Anti-inflammatory Activity of a Monofloral Honey of Mimosa scabrella provided by Melipona marginata During Winter in Southern Brazil. Journal of Medicinal Food, 17(7), 817-825. https://doi.org/10.1089/jmf.2013.0024

Chanchao, C. (2009). Antimicrobial Activity by Trigona Laeviceps (Stingless bee) Honey from Thailand. Pakistan Journal of Medical Science, 25(3), 364369.

Codex. (2001). Revised Codex Standard for Honey, CODEX STAN 12- 1981. Retrieved from http:// www.fao.org/fao-who-codexalimentarius/en/.

Crespo, I., García-Mediavilla, M.V., Almar, M., González, P., Tuñón, M.J., Sánchez-Campos, S. and González-Gallego, J. (2008). Differential effects of dietary flavonoids on reactive oxygen and nitrogen species generation and changes in antioxidant enzyme expression induced by proinflammatory cytokines in Chang Liver cells. Food and Chemical Toxicology, 46(5), 1555-1569. https:// doi.org/10.1016/j.fct.2007.12.014

De Sousa, J.M., de Souza, E.L., Marques, G., Meireles, B., de Magalhães Cordeiro, Â.T., Gullón, B. and Magnani, M. (2016). Polyphenolic profile and 
antioxidant and antibacterial activities of monofloral honeys produced by Meliponini in the Brazilian semiarid region. Food Research International, 84, 61 -68. https://doi.org/10.1016/j.foodres.2016.03.012

Demera, J. and Angert, E. (2004). Comparison of the antimicrobial activity of honey produced by Tetragonisca angustula (Meliponinae) and Apis mellifera from different phytogeographic regions of Costa Rica. Apidologie, 35 (4), 11-417. https:// doi.org/10.1051/apido:2004033

Duarte, A.W.S., Santos Vasconcelos, M. R., Domarques de Menezes, A.P., Chagas da Silva, S., Oda-Souza, M. and Queijeiro López, A.M. (2012). Composition and antioxidant activity of honey from Africanized and stingless bees in Alagoas (Brazil): a multivariate analysis. Journal of Apicultural Research, 51(1), 23 35. https://doi.org/10.3896/IBRA.1.51.1.04

Ewnetu, Y., Lemma, W. and Birhane, N. (2013). Antibacterial effects of Apis mellifera and stingless bee honeys on susceptible and resistant strains of Escherichia coli, Staphylococcus aureus and Klebsiella pneumoniae in Gondar, Northwest Ethiopia. BMC Complementary and Alternative Medicine,13, 269. https://doi.org/10.1186/1472-6882 $-13-269$

Fowler, H.G. 1979. Responses by a stingless bee to a subtropical environment. Revista de Biología Tropical, 27(1), 111-118.

Garedew, A., Schmolz, E. and Lamprecht, I. (2004). Microcalorimetric investigation on the antimicrobial activity of honey of the stingless bee Trigona spp. and comparison of some parameters with those obtained with standard methods. Thermochimica Acta， 415, 99-106. https://doi.org/10.1016/ j.tca.2003.06.004

Ilechie, A.A., Kwapong, P.K., Mate-Kole, E., Kyei, S. and Darko-Takyi, C. (2012). The efficacy of stingless bee honey for the treatment of bacteriainduced conjunctivitis in guinea pigs. Journal of Experimental Pharmacology, 4, 63-68. https:// doi.org/10.2147/JEP.S28415

Kimoto-Nira, H. and Amano, K. (2008). Antimicrobial activity of honey produced by stingless honey bees. Journal of Apicultural Research, 47(4), 325-327. https://doi.org/10.1080/00218839.2008.11101484

Kustiawan, P.M., Songchan, P., Enos, T.A. and Chanpen, C. (2014). In Vitro Cytotoxicity of Indonesian Stingless Bee Products against Human Cancer Cell Lines. Asian Pacific Journal of Tropical Biomedicine, 4(7), 549-556. https:// doi.org/10.12980/APJTB.4.2014APJTB-2013-0039
Larrosa, M., Luceri, C. and Vivoli, E. (2009). Polyphenol metabolites from colonic microbiota exert anti-inflammatory activity on different inflammation models. Molecular Nutritional and Food Research, 53, 1044- 1054. https:// doi.org/10.1002/mnfr.200800446

Massaro, C.F., Shelley, D., Heard, T.A. and Brooks, P. (2014). In Vitro Antibacterial Phenolic Extracts from "Sugarbag" Pot-Honeys of Australian Stingless Bees (Tetragonula carbonaria). Journal of Agriculture and Food Chemistry, 62(50), 12209-12217. https:// doi.org/10.1021/jf5051848

Medeiros, V. de F.L.P., Azevedo, Í.M., Rêgo, A.C.M., Egito, E.S.T. do, Araújo-Filho, I. and Medeiros, A.C. (2016). Antibacterial properties and healing effects of Melipona scutellaris honey in MRSA-infected wounds of rats. Acta Cirurgica Brasileira, 31(5), 327 -332. https://doi.org/10.1590/S0102865020160050000006

Merces, M.D., Peralta, E.D., Uetanabaro, A.P. and Lucchese, A.M. (2013). Antimicrobial activity of honey from five species of Brazilian stingless bees. Ciência Rural, Santa Maria, 43(4), 672-675.

Miorin, P.L., Levy Junior, N.C., Custodio, A.R., Bretz, W.A. and Marcucci, M.C. (2003). Antibacterial activity of honey and propolis from Apis mellifera and Tetragonisca angustula against Staphylococcus aureus. Journal of Applied Microbiology, 95, 913$920 . \quad$ https://doi.org/10.1046/j.13652672.2003.02050.x

Molan, P.C. (1992). The antibacterial activity of honey. The nature of the antibacterial activity. Bee World, 73, 5- $28 . \quad$ https:// doi.org/10.1080/0005772X.1992.11099109

Nishio, E.K., Carolina Bodnar, G., Regina Eches Perugini, M., Cornélio Andrei, C., Aparecido Proni, E., Katsuko Takayama Kobayashi, R. and Nakazato, G. (2016). Antibacterial activity of honey from stingless bees Scaptotrigona bipunctata Lepeletier, 1836 and S. postica Latreille, 1807 (Hymenoptera: Apidae: Meliponinae) against methicillin-resistant Staphylococcus aureus (MRSA). Journal of Apicultural Research, 54(5), 452-460

Nishio, E.K., Ribeiro, J.M., Oliveira, A.G., Andrade, C.G.T.J., Proni, E.A., Kobayashi, R.K.T. and Nakazato, G. (2016). Antibacterial synergic effect of honey from two stingless bees: Scaptotrigona bipunctata Lepeletier, 1836, and S. postica Latreille, 1807. Scientific Reports, 6(1), 21641.

Nobre da Cruz, C.B., Pieri, F.A., Carvalho-Zilse, G.A., Orlandi, P.P., Nunes-Silva, C.G., and Leomil, L. 
(2014). Antimicrobial activity of honeys from two stingless honeybee species and Apis mellifera (Hymenoptera: Apidae) against pathogenic microorganisms. Acta Amazonica, 44(2), 287 - 290. https://doi.org/10.1590/S0044-59672014000200015

Özbalci, B., Boyaci, I.H., Topcu, A., Kadilar, C. and Tamer, U. 2013. Rapid analysis of sugars in honey by processing Raman spectrum using chemometric methods and artificial neural networks. Food Chemistry, 136(3-4): 1444-1452. https:// doi.org/10.1016/j.foodchem.2012.09.064

Pe'rez, E., Rodríguez-Malaver, A.J. and Vit, P. (2006). Antioxidant capacity of Venezuelan honey in wistar rat homogenates. Journal of Medical Food, 9(4), 510 $-516$.

Porcza, L.M., Simms, C. and Chopra, M. 2016. Honey and Cancer: Current Status and Future Directions. Diseases, 4(4), 30. https://doi.org/10.3390/ diseases 4040030

Queiroz, P.R.B., Costa, C.A., Albuquerque, P.M. and Junior, S.D. (2013). Antimicrobial activity and rutin identification of honey produced by the stingless bee Melipona compressipes manaosensis and commercial honey. BMC Complementary and Alternative Medicine, 13, 151.

Rahman, T, Hosen, I, Towhidul Islam, M.M. and Shekhar, H.U. (2012). Oxidative stress and human health. Advances in Bioscience and Biotechnology, 3, 997-1019. https://doi.org/10.4236/abb.2012.327123

Rodríguez, C.D., Ramón-Sierra, J., Lope-Ayora, J., Sauri -Duch, E., Cuevas-Glory, L. and Ortiz-Vázquez, L. (2012). Antibacterial Properties of Honey Produced by Melipona beecheii and Apis mellifera against Foodborne Microorganisms. Food Science Biotechnology, 21(3), 905-909. https:// doi.org/10.1007/s10068-012-0118-x

Roowi, S., Muhamad, S.A., Sipon, H., Jaafar, M.F., Daud, M.N.H. and Othman, R. (2012). Asid fenolik bebas dalam madu Kelulut. Buletin Teknologi MARDI, 2, 145-147.

Shashank, K. and Abhay, K. 2013. Review Article Chemistry and Biological Activities of Flavonoids: An Overview. The Scientific World Journal, 4(2), 32 -48. http://dx.doi.org/10.1155/2013/162750

Souza., B., Roubik, D., Barth, O., Heard, T., Enríquez E., Carvalho, C., Villas-BôAs, J., AlmeidaMuraidan, L., Bogdanov, S. and Vit, P. (2006). Composition of stingless bee honey: setting quality standards. Interciencia, 31, 867-875.

Temaru, E., Shimura, E. Amano K. and Karasawa, T.
(2007). Antibacterial Activity of Honey from Stingless Honeybees (Hymenoptera; Apidae; Meliponinae). Polish Journal of Microbiology, 56 (4), 281-285.

Yazan, L.S., Muhamad Zali, M.F.S., Ali, R.M., Zainal, N.A., Esa, N., Sapuan, S. and Syed Alwi, S.S. (2016). Chemopreventive Properties and Toxicity of Kelulut Honey in Sprague Dawley Rats Induced with Azoxymethane. BioMed Research International, 2016.

Zainol, M.I., Yusoff, K.M. and Mohd Yusof, M.Y. (2013). Antibacterial activity of selected Malaysian honey. BMC Complementary and Alternative Medicine, 13, 129. https://doi.org/10.1186/1472-688213-129

Zamora, G., Beukelman, K., Berg, B.V.D., Arias, M.L., Umaña, E., Aguilar I., Sánchez, L. A., Fallas, N., Ufford, L.Q.V. and Gross, N. (2014). The antimicrobial activity and microbiological safety of stingless bee honeys from Costa Rica. Journal of Apicultural Research, 53(5), 503-513. https:// doi.org/10.3896/IBRA.1.53.5.04 